\title{
Preliminary Analysis of the Failure of Well EW-5,Visalia Pole Yard, February 1, 1999
}

\author{
R. Aines
}

R. Newmark

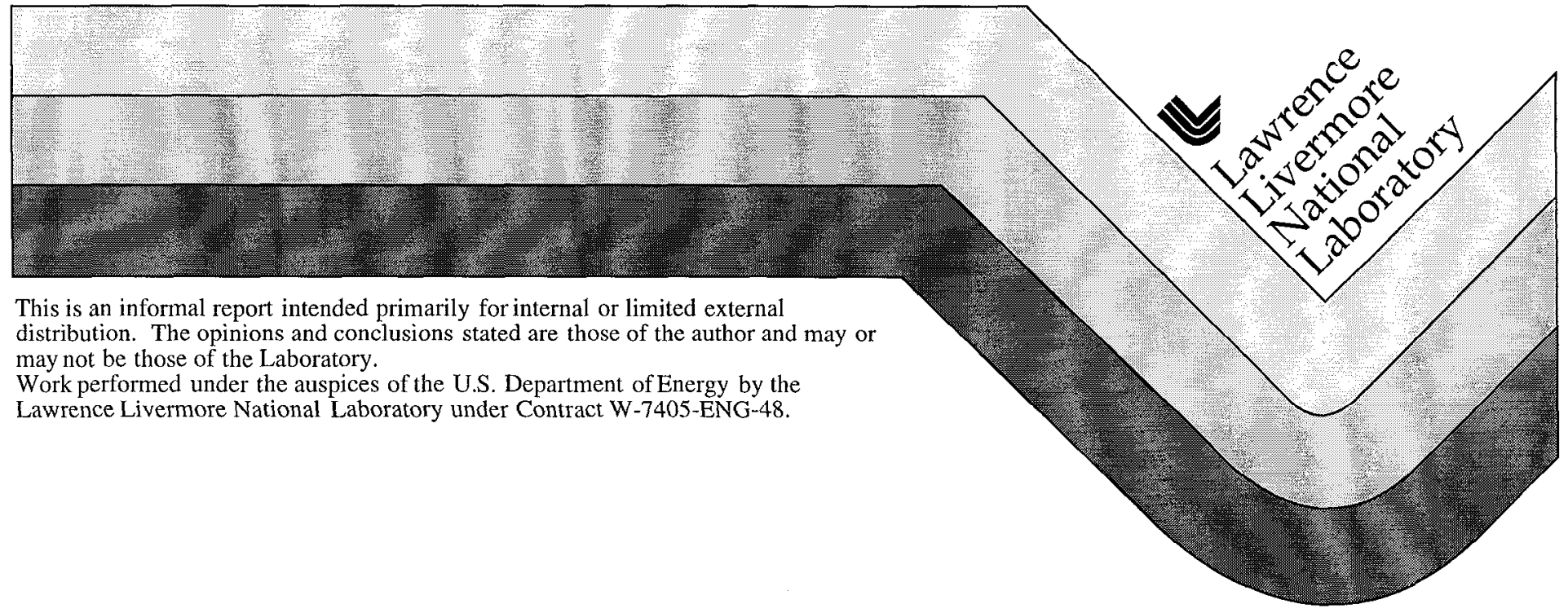




\section{DISCLAIMER}

This document was prepared as an account of work sponsored by an agency of the United States Government. Neither the United States Government nor the University of California nor any of their employees, makes any warranty, express or implied, or assumes any legal liability or responsibility for the accuracy, compleleness, or usefulness of any information, apparalus, producl, or process disclosed, or represents that its use would not infringe privately owned rights. Reference herein to any specific commercial product, process, or service by trade name, trademark, manufacturer, or otherwise, does not necessarily constitute or imply its endorsement, recommendation, or favoring by the United States Government or the University of California. The views and opinions of authors expressed herein do not necessarily state or reflect those of the United States Government or the University of California, and shall not be used for advertising or product endorsement purposes.

This report has been reproduced directly from the best available copy.

Available to DOE and DOE contractors from the Office of Scientific and Technical Information

P.O. Box 62, Oak Ridge, TN 37831

Prices available from (423) 576-8401

Available to the public from the

National Technical Information Service

U.S. Department of Commerce

5285 Port Royal Rd.

Springfield, VA 22161 


\section{Preliminary analysis of the failure of well EW-5, Visalia Pole Yard, February 1, 1999}

Roger Aines and Robin Newmark
Lawrence Livermore National Laboratory

\section{Events}

EW-5 Steam Venting On February 1 at about 9:30 a.m., operators (John Dyda's account) heard a loud roaring sound coming from the vicinity of the treatment plant. Through a heavy fog, they could see a large column of steam erupting out of well EW-5. The sound of the eruption varied throughout the day, indicating changes in flow rate or path. Occasional louder bursts were heard as well. In the afternoon the intensity of the sound diminished. Photographs from the afternoon show a steam plume reaching at least $100 \mathrm{ft}$ into the air.

Steam injection into S $14 \mathrm{D}$ and S 9D, which had been ongoing at about $15,000 \mathrm{lb} / \mathrm{hr}$ each, was halted immediately. Extraction from S 9D continued, while EW 5 extraction was halted. The vacuum system was shut down due to the need to burn the extracted vapor in the boiler, which had to be shut down since there was no place to safely inject the steam produced. Attempts to quench the eruption with water, according to SCE procedure, failed due to the massive amount of steam coming out of the hole. At about 6:30 p.m. operalors began flooding well S-14D with cold water at a rate of about $100 \mathrm{gpm}$. This well is approximately $75 \mathrm{ft} \mathrm{NE}$ of well EW-5 and is completed in the same aquifer.

Eruption ceased suddenly at about 8:30 p.m.; this was attributed to the bridging of formation material in the open conduit. Once the eruption stopped, the well could be approached. At 9:30 p.m., quench water, at a rate of approximately $40 \mathrm{gpm}$, was introduced through a hole in the 8 " well casing; this hole was a remnant of the original quench port, which had broken off during the eruption.

Observation at 8:00 p.m., after eruption stopped, showed that the eruption had come from the 16" steel telescoping casing that had been used to protect the deep well from the introduction of nearsurface contamination during drilling. This casing ends at $107 \mathrm{ft}$ depth, according to construction logs. A plumb weight was used to tag the casing, showing a hard obstruction at $31 \mathrm{ft}$ depth at that time. At 9:30 p.m. the 16" casing was completely empty, and clean, bubbling water could be seen within it at about 40 to $50 \mathrm{ft}$ depth. After one hour of injecting quench water into the 8 " casing, the water in the 16" casing was no longer bubbling and was crystal clear. The bottom of the water could not be seen. The next morning, Craig Eaker tagged the bottom of the water zone (which is, presumably, the top of the bridge) at $91.8 \mathrm{ft}$ bgs.

SCE personnel appeared to follow all applicable safety procedures. There were no injuries from this event.

Ejecta Analysis Throughout the day of February 1, sand and silt rained out of the steam plume. Near the wellhead, streaks of brown could be seen in the steam as it rushed upward. The majority of observed ejecta fell in a quadrant approximately centered due east of the well, so that about half of the material fell on the Visalia City Yard property (Figure 1 is a map of the Pole Yard and well locations). On February 2, the depth of this material was measured radially away from the EW-5 well, approximately in an easterly direction in the City yard. Observed depths were: 


$\begin{array}{ll}4 " & \text { to approx. } 30 \mathrm{ft} \\ 2 " & \text { to approx. } 50 \mathrm{ft} \\ 1 " & \text { to approx. } 70 \mathrm{ft} \\ 1 / 2 " & \text { to approx. } 100 \mathrm{ft} \\ 1 / 4 " & \text { to approx. } 200 \mathrm{ft}\end{array}$

A substantial amount of sand was observed to the eastern edge of the SCE property, sufficient to coat horizontal surfaces and impart a uniform tan color to objects.

Depths were uneven, and considerable washing of the fallout had apparently occurred, demonstrated by the presence of some channels, winnowing, and surface coverings of coarse sand underlain by more silt-rich material. The fallout pattern was assumed to be approximately radial, covering a section of $1 / 3$ of a circle around the well, centered eastward. The above depths indicated a total amount of material between 20 and 50 cubic yards. Cleanup crews later removed 15 cubic yards of material from the city yard, validating this estimate assuming that one half of the fallout landed on City property.

Two types of ejecta were observed on February 2. The majority of the material was fine-grained silt and sand and appeared to be formation material. Some small stones were observed, but very rarely (less than $0.1 \%$ of the material). The second type was lumps, $1 / 4$ " to 1 " in diameter, of bentonite clay from the completion material. This material was found only within $25 \mathrm{ft}$ of the well, predominantly within $10 \mathrm{ft}$. Material this close to the well appeared to be well-washed by water fall from the plume, but bentonite was always under the other material and often firmly stuck to pipes and to the side of the separator. This may be interpreted to mean that the bentonite came out first and at a lower velocity than the later ejecta.

The temperature of the plume was not measured; however, relatively little of the plume fell as water, indicating a large steam fraction.

Subsurface Temperatures Temperatures measured in wells ERT-4 (25 ft W of EW-5) and ERT-5 $\left(50 \mathrm{ft} \mathrm{N}\right.$ of EW-5) showed deep-aquifer temperatures of $138-140^{\circ} \mathrm{C}$, slightly above the boiling point $\left(\sim 135^{\circ} \mathrm{C}\right)$ at that depth due to the applied hydrostatic head before the eruption. Temperatures of $140^{\circ} \mathrm{C}$ correspond to steam pressure of $38 \mathrm{psig}$. The approximate lithology is shown in Figure 2. Temperature logs before, during, and after the eruption are shown in Figure 3. The above-boiling-point temperatures were not unusual for steam-injection operations; this is a common degree of overpressure.

Logs of wells ERT-1 and -2, in particular, show that the boiling-point temperatures had encroached into the aquitard up to depths of $110 \mathrm{ft}$, approximately $10 \mathrm{ft}$ into the aquitard material. "Huff and puff" operation of a steaming process is intended to ratchet the steam zone into aquitard materials by slightly overpressuring them, then releasing the pressure, which causes any portion of the aquitard above the new boiling point to be disrupted by steam generation. This mechanism was apparently active in the progress of the steam zone upward into the aquitard, and can readily be imagined to have contributed to liquefying bentonite in the well completion and potentially removing it by stoping processes, causing the bentonite to fall out of the conductor casing. Settling and mobilization of fines during previous steaming may have created some void space below the bentonite in the filter pack (around the screen), starting the stoping process.

MW-34 Mud Venting In January, well MW-34 (NE of the office building) vented bentonite mud and was successfully quenched by applying water from the quench system (details on this event are incomplete). This well is completed in the deep aquifer and uses construction methods similar to EW-5. The $107 \mathrm{ft}$ conductor casing in well MW 34 is 10" diameter. According to Billy Milam, mud erupted from both the top of the well (the yellow "can" surrounding the 4" 
casing) and from under the concrete pad. Mud was thrown high enough to hit the top of the nearby stairs. No steam escaped.

The MW 34 mud event appears similar to the EW-5 eruption. Analysis of why it proceeded slowly and responded to normal quenching procedures will be valuable. This well had been actively cooled using LLNL's circulating cooling system until mid December, when the cooling systems were removed from all 4 pre-existing PVC wells (MW 34 and 44 in the deep aquifer, MW 36 and 41 in the intermediate aquifer).

\section{Photos}

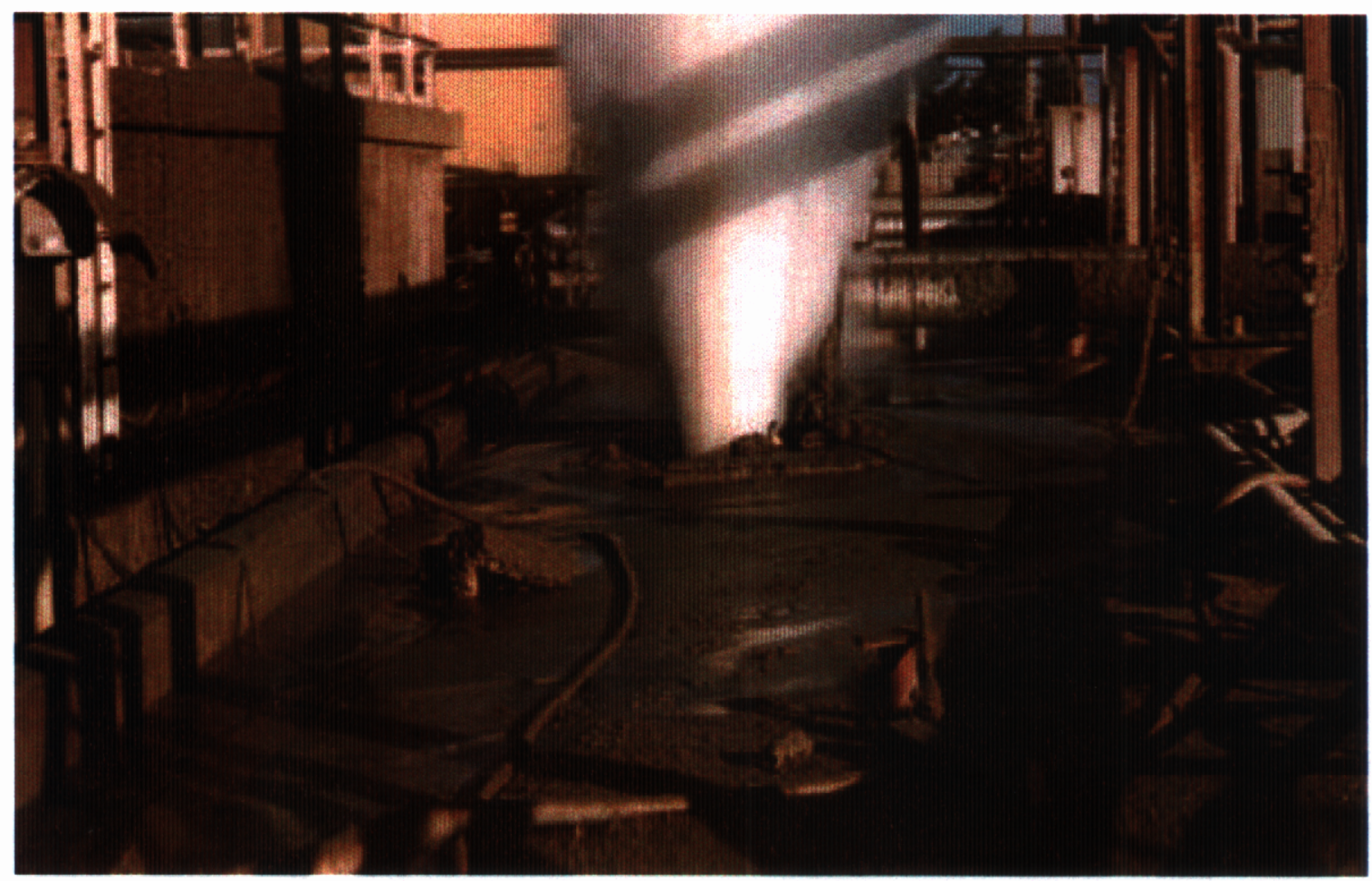

Geyser during eruption (from the west). A dislodged, triangular chunk of concrete from the well cap lies at center left. Streaks of brown silt may be seen in the plume. Bentonite that appeared to have erupted by an early, much less vigorous process is stuck to the separator wall at the left. 


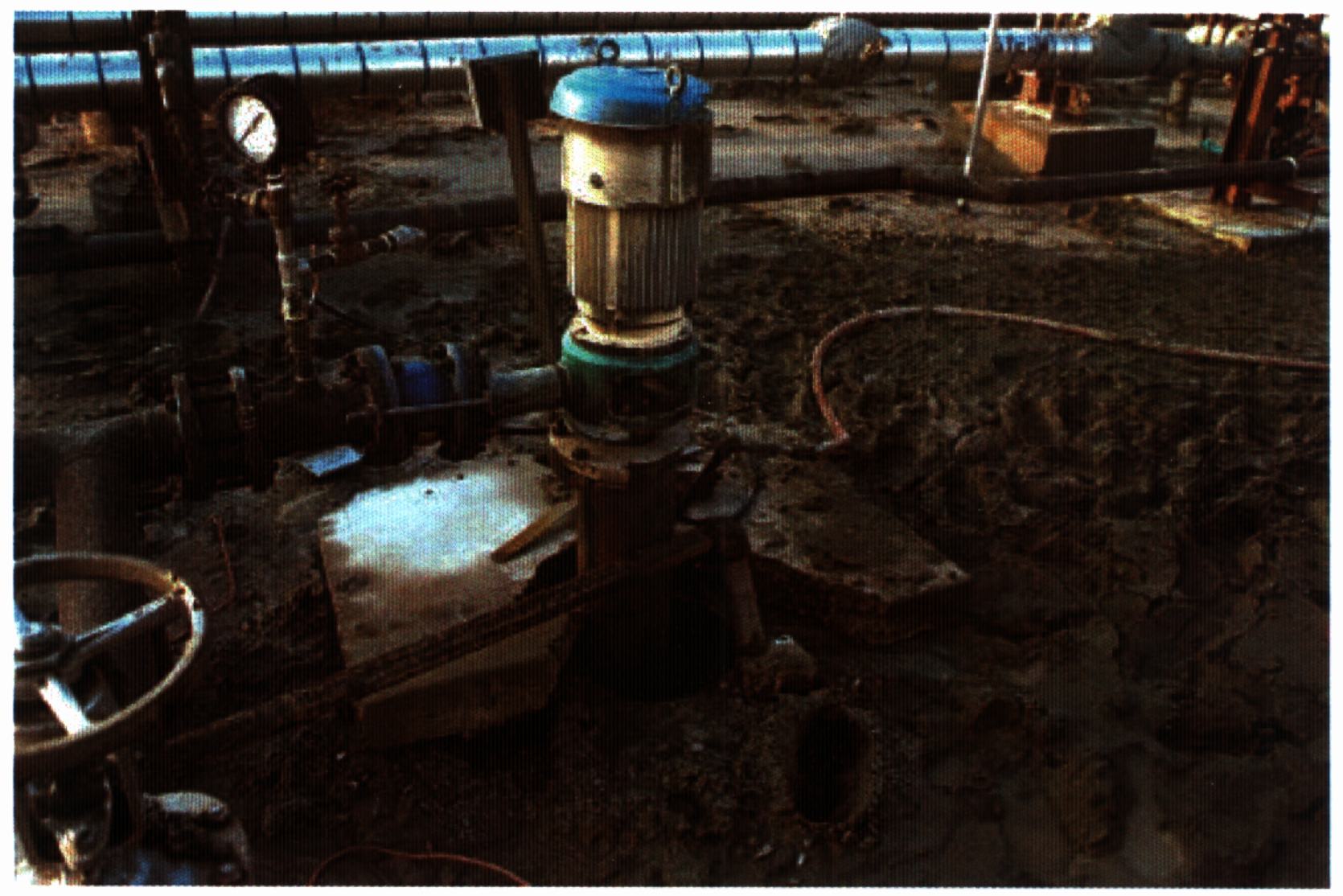

Quenched well on February 2, from the foundation of the separator (north of the well). The 2" pipe from left was used in attempting to quench the well. The concrete cap had cracked behind the upright well casing. Mud is under the concrete, indicating that the cap had been raised while mud escaped and implying that the triangular chunk broke out after some eruption had occurred. 

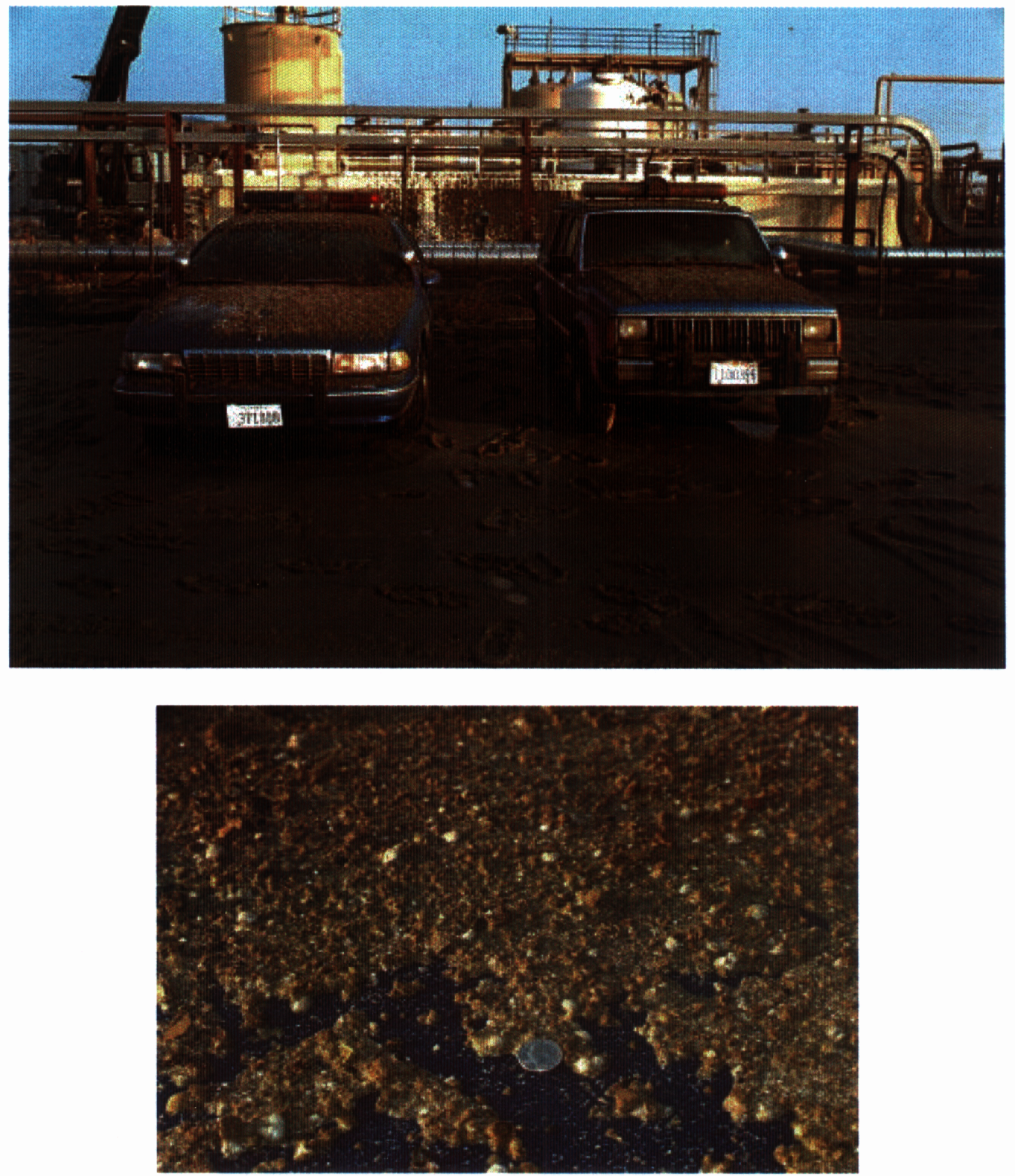

Ejected mud and silt. Lower photo shows detail from the back of the police sedan. Chunks are almost all bentonite; quarter is for scale. Well EW-5 can be seen in the background between the vehicles. Silt depth in front of these vehicles was about 1 inch. 


\section{Analysis and Physical Causes}

Open conduits to the steam zone have long been a concern in the application of steam remediation. The first large-scale geyser occurred in the clean-site test conducted in 1991. That geyser was successfully controlled by application of cold water. Since then, DUS applications, including Visalia, have incorporated dedicated quench ports on all wells. The EW-5 eruption occurred via a conduit that was not anticipated and not addressable by the existing quench mechanisms.

The source of this eruption was the $16 "$ conductor. The conductor casing was filled with bentonite, which apparently became liquefied and lost strength, allowing bubbles of steam to rise through it, removing the bentonite. This assessment is based on the mud eruptions from MW-34 and the apparently low-energy mud splattering around EW-5; there are currently no eyewitness accounts to verify that mud came out slowly at the beginning of the event. Personnel from the Visalia City Corporation Yard should be consulted conerning supplying more information about this inference.

Once the majority of the bentonite mud was removed, the simple lifting force of the 38-psi aquifer steam pressure was sufficient to lift the concrete pad over the well. Approximately $5000 \mathrm{lb}$ of lift could be generated (the pad occupied 150 square inches, including the area removed by the 8 " casing). The concrete pad originally surrounded the intact 8 " well casing, but the pad fractured and a triangular chunk was found about $8 \mathrm{ft}$ away. This failure allowed the steam direct access to the surface. The initial eruption would have almost certainly been water lifted by steam, but with the insulation of the steel conductor casing, the steam eruption would then continue unabated. It is likely that the initial lifting of the concrete sheared off the quench valve, which was welded into the 8 " casing about 18 " from ground surface. The valve was found in the mud about $3 \mathrm{ft}$ to the west of well EW-5, without any of the traces of sandblasting that other metal in the wellhead evidenced.

Thermal analysis of changes in aquifer temperature indicates that the deep aquifer yielded steam throughout the area monitored by temperature wells. The temperature dropped quickly to just below the applied boiling point, which would be expected as the applied pressure on the aquifer was reduced by communication with the geyser. After the geyser stopped, overall temperatures in the aquifer had been reduced by an average of $11.9^{\circ} \mathrm{C}$. This value can be considered together with the heat capacities of soil and water to estimate that approximately 1.9 billion BTUs were released (attached calculations). If this thermal energy were used to generate steam at a constant $135^{\circ} \mathrm{C}$, an average of about $174,000 \mathrm{lb} / \mathrm{hr}$ (average) of steam would be produced over the 12 hours of eruption time. This calculation is preliminary and depends on several major assumptions, including the size of the communicating steam zone; it does not take into account other fluid movement or the pressure-volume (PV) work done on expansion.

The magnitude of the steam released indicates why the well could not be quenched with water applied from the top.

Temperature logs indicate that the eruption continued isothermally, but with some gradual increase in applied aquifer pressure indicating a smaller steam zone and encroaching formation water. At some point there would eventually have been no energy left to produce steam, but the eruption stopped much more suddenly than simple energy loss could indicate. Apparently the gravel and sand suspended in the eruption column became too heavy, and as the eruption slowed the gravel fell back into the well. This material bridged against itself and the two concentric pipes, reducing the flow velocity dramatically. The accompanying pressure increase below that point would have instantly quenched the steam zones, which were below the boiling-point temperature at the natural aquifer pressure. Quench water added through the 8 " well casing at this point further cooled the system and ensured no further eruptions would occur. 
Quench water added to well S-14 provided a very small amount of overall cooling compared to the heat release through the geyser (see calculations), but resulted in a significant decrease in the 135-ft temperatures in ERT-1. This creation of a cold spot in the aquifer may have changed the aquifer pressure gradients enough to slow the eruption rate, allow the bridge to form, and stop the eruption. Further analysis of this effect is warranted, because it may be a very viable option for reducing the effect of similar events where there is no opportunity to directly cool the failure location.

Temperature logs indicate that the entire aquifer was producing steam, and that most of the heat loss occurred in the aquifer from 115 to $135 \mathrm{ft}$. The aquitard from 107 to $115 \mathrm{ft}$ showed little permanent temperature change in the monitoring wells, which may have experienced different flow than the region of well EW-5. Based on this data, however, it appears that steam flowed through the aquifer horizontally to the EW-5 well, where vertical flow eroded the aquitard material as it passed up and into the casing at $107 \mathrm{ft}$. The soil removed by the eruption appears to have been consistent in mineralogy and chemistry to that originally logged just below the conductor casing in the drilling of this well. Electric casing logs run after the eruption showed potential voids from about $100 \mathrm{ft}$ to $130 \mathrm{ft}$, the top of the screened zone. This area accepted approximately 24 cubic yards of grout after the casing was perforated.

\section{Findings}

The root cause of this failure was the bentonite grout within the deep conductor casing. Bentonite cannot be relied upon to seal steam wells.

The concrete cap on the well was not heavy enough to contain the pressure from the steam zone once the bentonite liquefied. The cap was unreinforced and broke into several pieces. The small size and fragile nature of this cap may be the reason that this event turned into a large eruption, in contrast to the MW-34 mud eruption, which was easily quenched by existing procedures.

The quench system might have been capable of calming the well in the initial (unseen) stages of the failure, but the quench port was removed by the concrete cap movement, or venting steam and sand. It clearly would have provided inadequate cooling capacity when the geyser was operating fully, at which time a cooling capacity capable of condensing a significant fraction of several hundred thousand pounds of steam per hour would have been required. Oil-field practices should be followed for further deep injections in which this amount of stored energy is available. Quench water needed to have been applied at the aquifer level to be effective.

A method for verifying the integrity of wells in deep steam-injection zones should be developed and employed.

Wells MW-34, MW-44, and any other bentonite-grouted wells in the deep aquifer should be destroyed by drilling out the bentonite and grouting with high-temperature cement grout.

The factors causing the eruption to stop include the loss of formation energy, addition of quench water to S-14D, and formation of a bridge in the bottom of the conductor casing. The relative contributions of these factors are not yet known and warrant further study.

Edison personnel followed all applicable safety procedures and are to be commended that no one was injured during this event. 


\section{Figures}

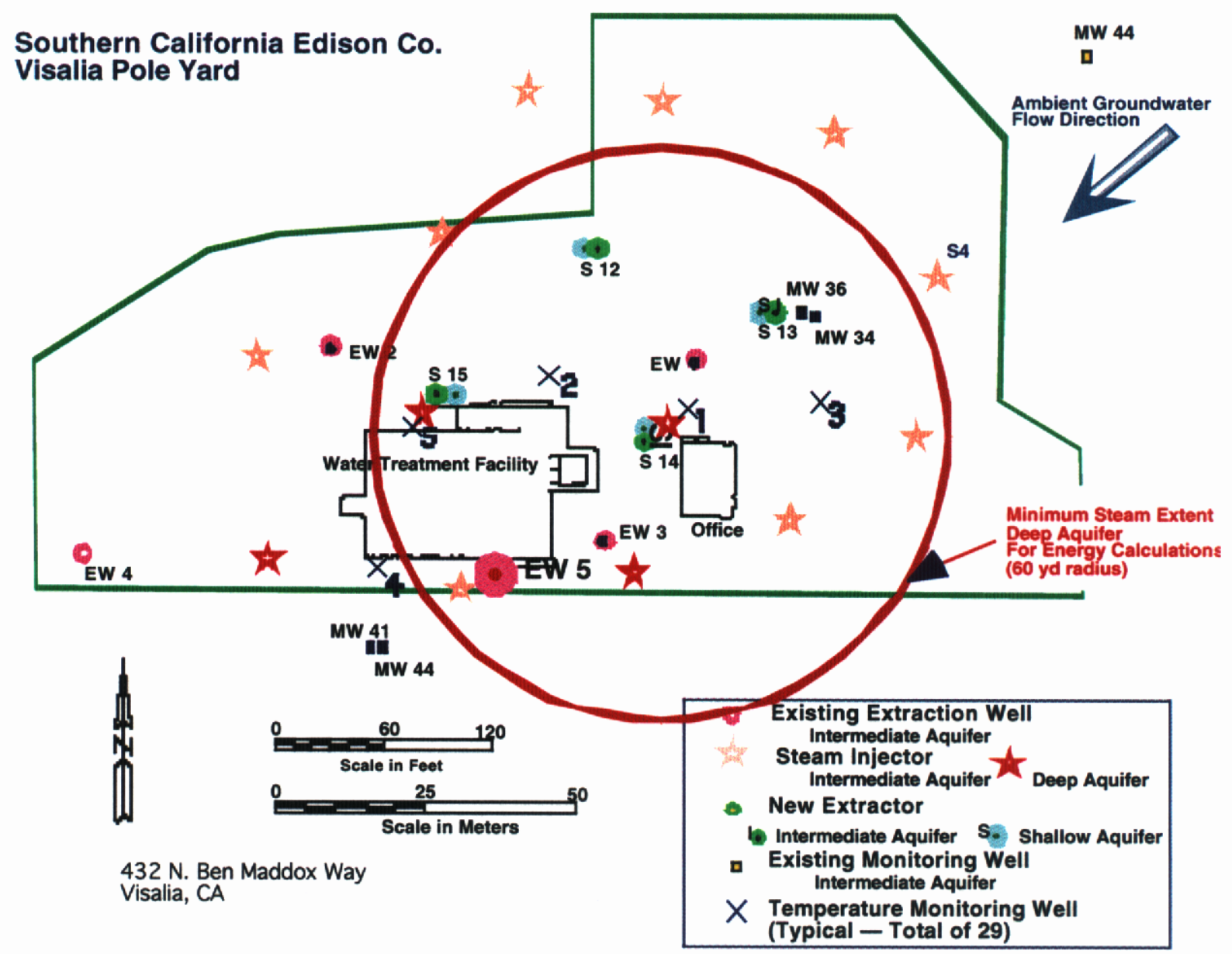

Figure 1. Map of the monitoring and operational wells used for deep-aquifer treatment at Visalia. 


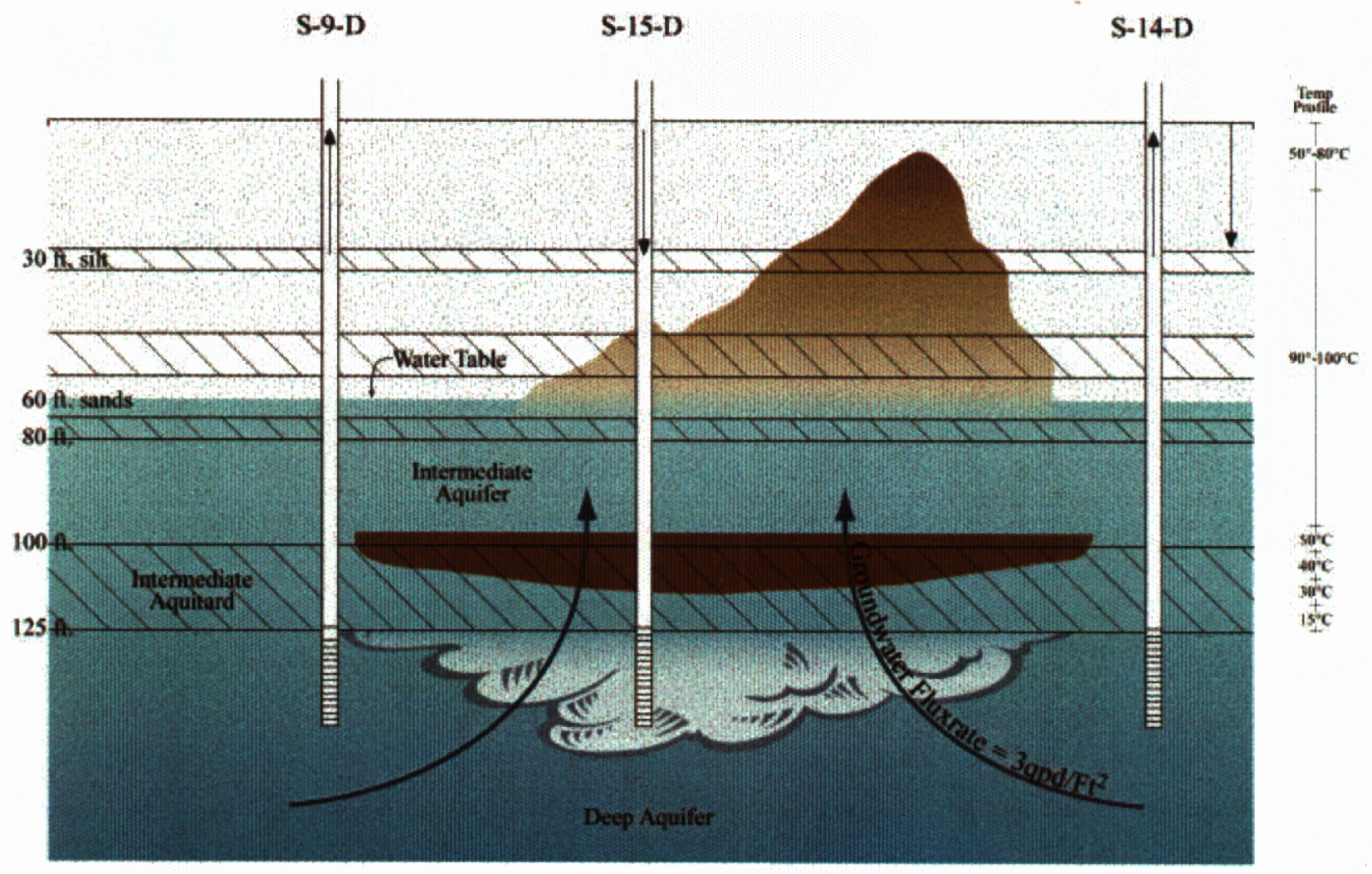

\section{Visalia Steam Remediation Project Phase II Steam Injection}

Figure 2. Edison conceptual drawing of the heating of the deep aquitard by injection of steam into the deep aquifer. 


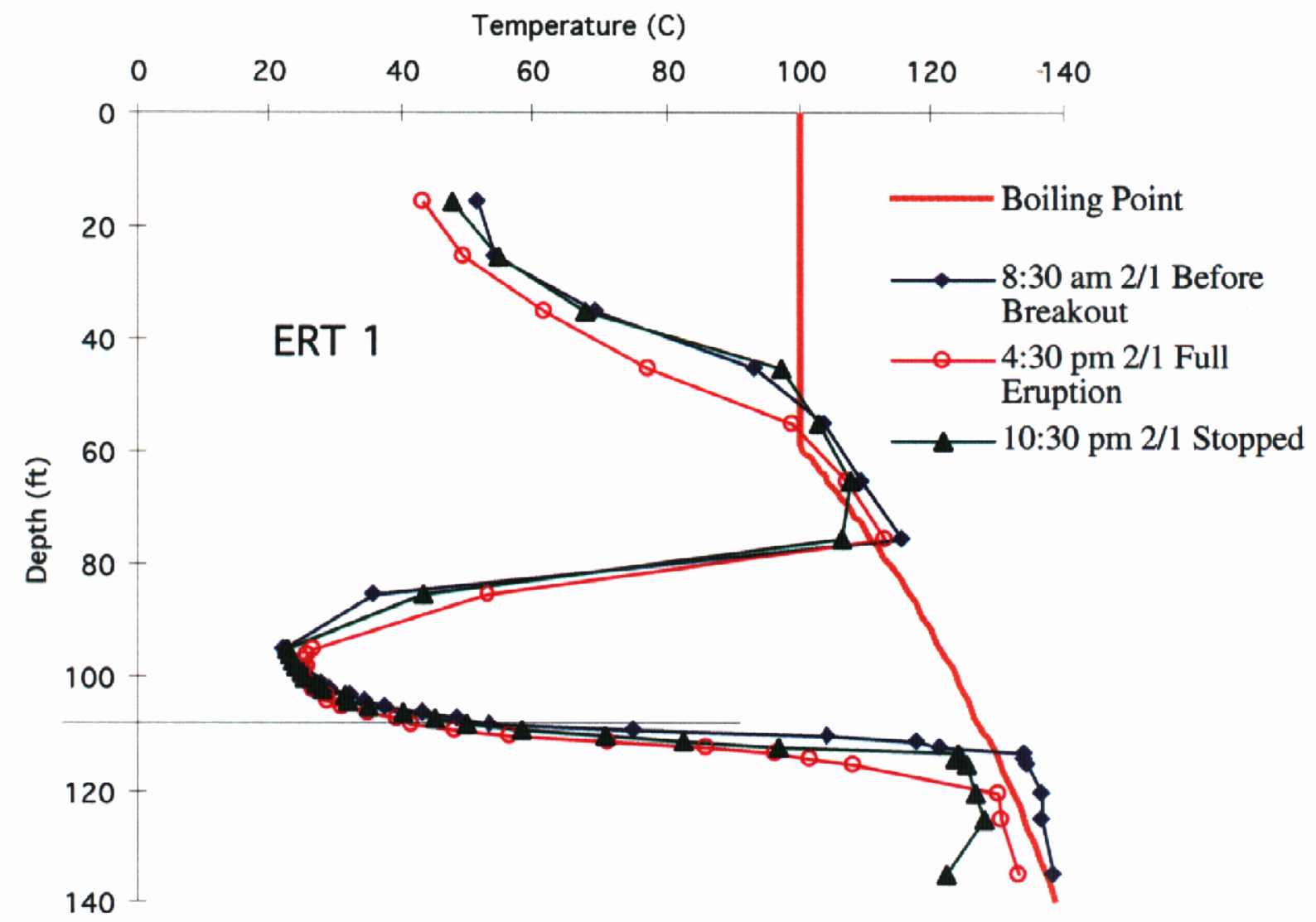




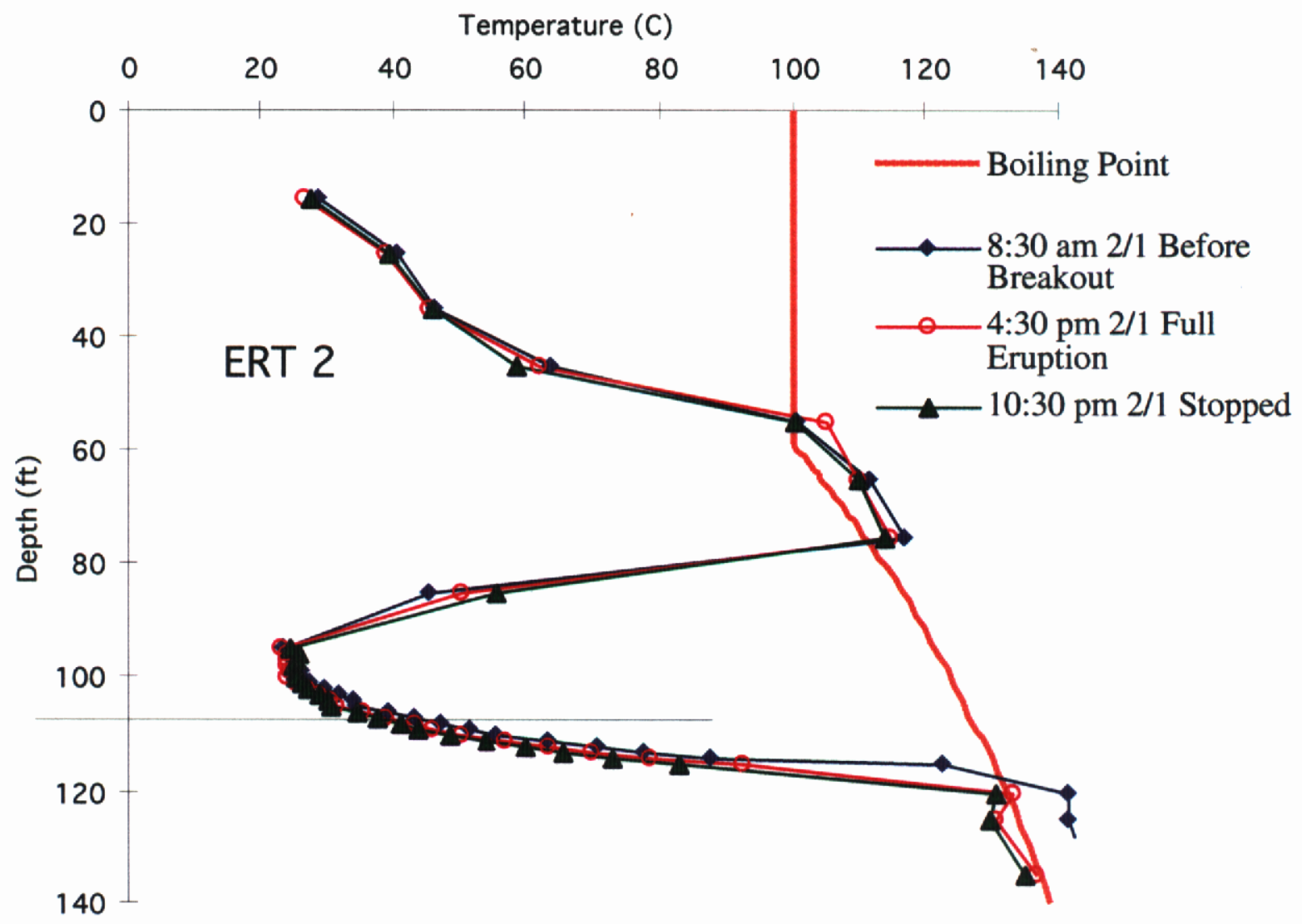




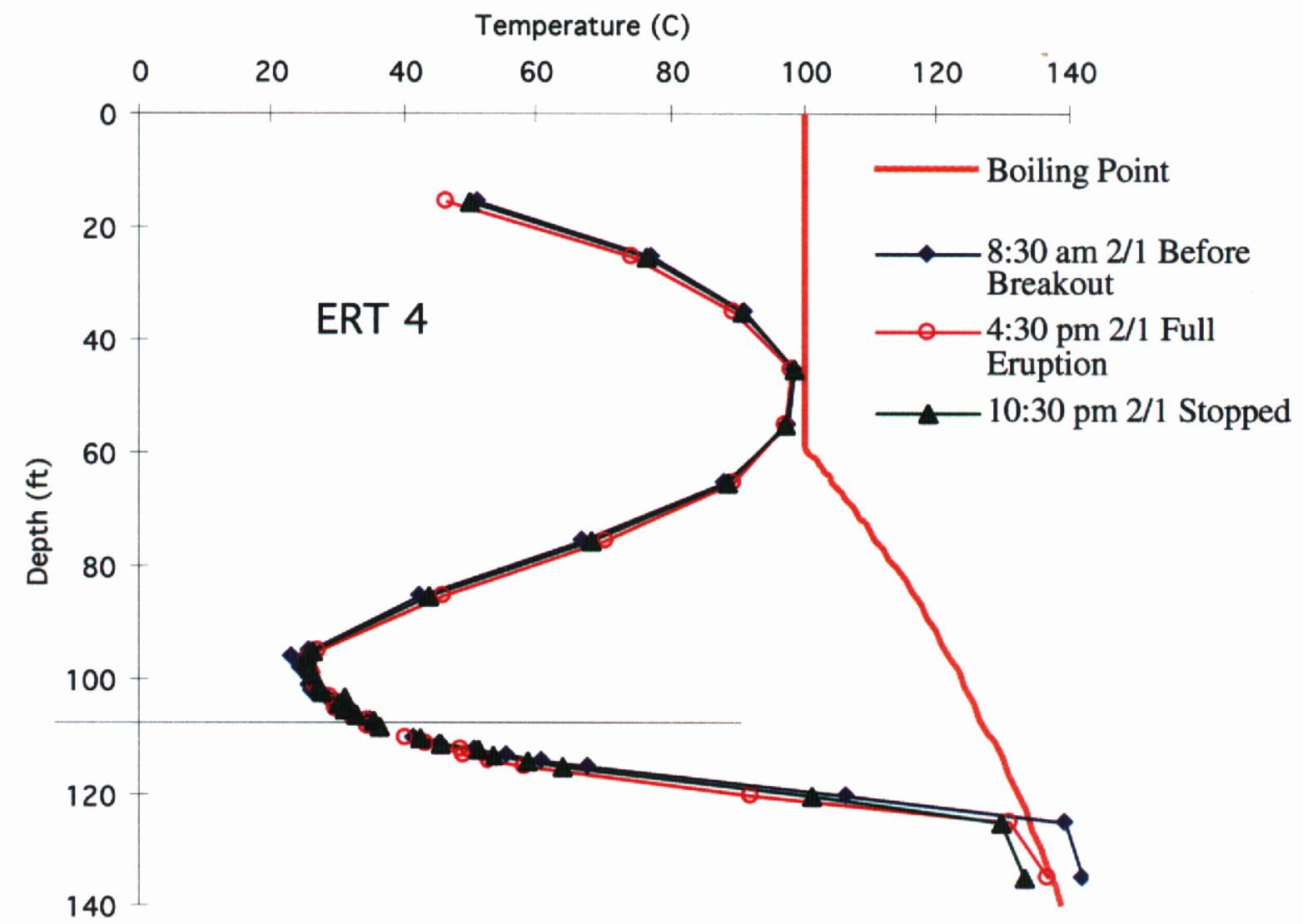




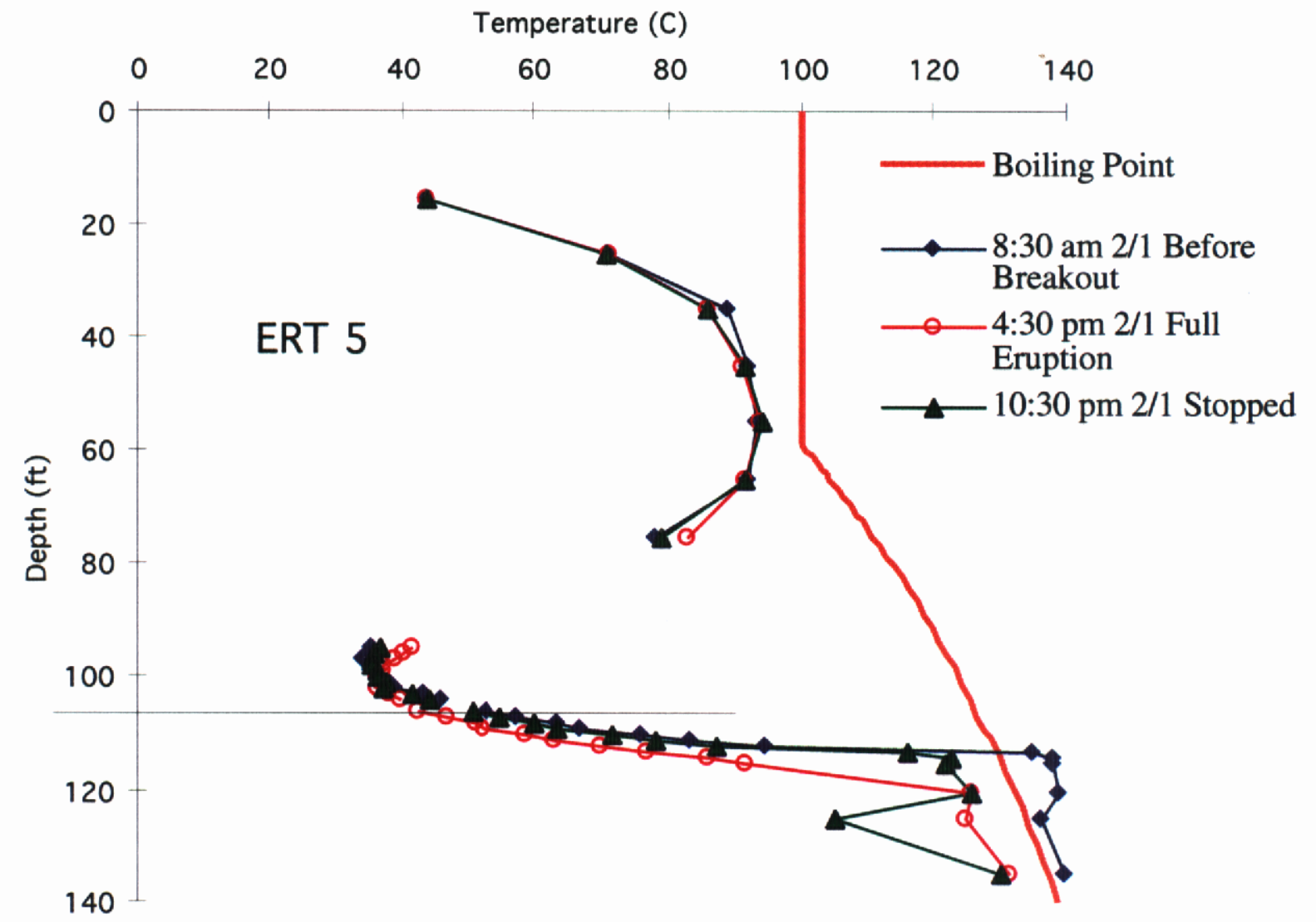

Figure 3. Temperature profiles as a function of depth for the four closest monitoring wells before, during, and after the eruption on February 1, 1999. The horizontal line is approximately at the depth of the conductor casing. The boiling point line is calculated from water levels in the two aquifers (hence the small offset at about $110 \mathrm{ft}$; the lower aquifer has a head about two feet taller than the upper). This calculation may not precisely reflect the natural boiling point in all locations-e.g., ERT-2 appears to be slightly above the calculated boiling point in the upper regions, for which there is no apparent lithologic or hydrologic basis. Breaks in the curves (e.g., at $85 \mathrm{ft}$ in ERT-5) indicate failed thermocouples. The notable offset in the full-eruption temperatures in ERT-1 are probably due to the presence of water in the temperature monitoring tube, slightly supported by a steam bubble near the bottom. When temperatures collapsed, the bubble collapsed and allowed water in the tube to drop lower. This caused a temporary offset in the observed temperatures. This log indicates that the water dropped several feet. The formation temperatures quickly re-equilibrate the water in the tube, which is 2 " in diameter and filled with sand. 


\section{Analyses}

\section{1) Assess average temperature change in reservoir}

Average decline, all five wells (ERT 1-5):

$135-115^{\prime}, 11.9^{\circ} \mathrm{C}$

8:30 a.m. to $10: 30$ p.m.
Basic conversion data:

soil heat cap $\quad 0.2 \mathrm{cal} / \mathrm{g}{ }^{\circ} \mathrm{C}$

water heat cap $\quad 1.0 \mathrm{cal} / \mathrm{g}^{\circ} \mathrm{C}$

cc's per cubic yd $\quad 764,555 \mathrm{cc} / \mathrm{yd}$

\section{2) Determine how much heat loss the temperature represents}

A) How large is the volume (deep-aquifer volume contributing to geyser)?
Thickness
Radius (S-14D)
Volume
$7 \mathrm{yd}$
60 yd
$79,166 \mathrm{yd}^{3}$
$60.5 \times 10^{9} \mathrm{CC}$

B) How much soil and water is in that volume, and how much heat did it lose?

Water @ 20\% soil porosity

Total weight

Soil @ $3 \mathrm{~g} / \mathrm{cc}$ density

Total

$12.1 \times 10^{9} \mathrm{~g}$

cal @ avg decline

$145.3 \times 10^{9} \mathrm{~g}$

$143.7 \times 10^{9}$

$344.9 \times 10^{9}$

$488.6 \times 10^{9} \mathrm{cal}$

C) How much of the cooling was due to the cold water into S-14D?

gallons/minute

gallons/hr

100

grams/hr

6000

hours

$22.7 \times 10^{6}$

calories, $20^{\circ}$ to $135^{\circ} \mathrm{C} \quad-2.6 \times 10^{9} \mathrm{cal}$

D) Total heat change in aquifer, less the effect of the cooling water

total minus cold water

$$
\begin{gathered}
486.0 \times 10^{9} \text { calories } \\
=1.9 \times 10^{9} \mathrm{BTU} \\
=568 \mathrm{MW} \\
=761,600 \mathrm{HP}
\end{gathered}
$$

E) Average the effects over 12 hrs of eruption: $47 \mathrm{MW} / \mathrm{hr}=63,464 \mathrm{HP} / \mathrm{hr}$

\section{3) Calculate the amount of material, assuming steam was being generated at about $135^{\circ} \mathrm{C}$}

$927 \mathrm{BTU} / \mathrm{lbm}$ enthalpy to generate steam
A) Total steam generated at $135^{\circ} \mathrm{C}$
2,092,091 ib
261,511 gal
B) Average steam generated
$174,341 \mathrm{lb} / \mathrm{hr}$
$363 \mathrm{gal} / \mathrm{min}$ 